\title{
Pengelolaan ZIS dalam Upaya Meningkatkan Perekonomian Mustahik| Fitriana. Dkk \\ PENGELOLAAN ZIS DALAM UPAYA MENINGKATKAN PEREKONOMIAN MUSTAHIK (STUDI KASUS LAZISMU KL BMT HASANAH PONOROGO)
}

\author{
Nurma Fitrianna, Risma Khoirun Nazah, Muhammad Rendi Rifa'i , Diyah Ayu \\ Permatasasi, Suci Wahyu Lestari \\ Institut Agama Islam Negeri Ponorogo \\ nurmafitrianna89@gmail.com
}

\begin{abstract}
Abstrac:
This study aims to analyze the management of Zakat, Infak, and Alms (ZIS) funds at LAZISMU KL BMT Hasanah Ponorogo related to the management, fundraising, and distribution of ZIS funds to improve the mustahik economy. The research method uses a qualitative research model where data collection techniques are carried out by in-depth interviews and documentation over a period of one month. While the data analysis technique is done by reducing, presenting data, and drawing conclusions. The results of this study indicate that the management of ZIS funds at LAZISMU KL BMT Hasanah Ponorogo is not only done in traditional ways (consumptive in nature), but also productive. So from the production that has been done, it is hoped that it will be able to increase the mustahik economy. The fundraising technique used is door to door as well as online. Regarding the distribution of the collected ZIS funds, it is not only given to mustahik around the institution, but also throughout the Ponorogo Regency area so that its benefits will be more widespread.
\end{abstract}

Keywords: ZIS Management, ZIS Management Analysis, and Improving the Economy of Mustahik

\begin{abstract}
Abstrak:
Penelitian ini bertujuan untuk menganalisis pengelolaan dana Zakat, Infak, dan Sedekah (ZIS) di LAZISMU KL BMT Hasanah Ponorogo terkait dengan cara pengelolaan, fundraising, dan pendistribusian dana ZIS untuk meningkatkan perekonomian mustahik. Adapun metode penelitian ini menggunakan model penelitian kualitatif dimana teknik pengumpulan data dilakukan dengan wawancara secara mendalam dan dokumentasi selama kurun waktu satu bulan. Sedangkan teknik analisis data dilakukan dengan cara reduksi, penyajian data, dan penarikan kesimpulan. Hasil dari penelitian ini, menunjukkan bahwa pengelolaan dana ZIS di LAZISMU KL BMT Hasanah Ponorogo tidak hanya dilakukan dengan cara-cara tradisional (bersifat konsumtif), tetapi juga bersifat produktif. Sehingga dari pemproduktifan yang telah dilakukan diharapkan akan mampu meningkatkan perekonomian mustahik. Adapun teknik fundraising yang dilakukan adalah dengan cara door to door juga melalui online. Terkait dengan pendistribusian dana ZIS yang terkumpul tidak hanya diberikan untuk mustahik disekitar lembaga, tetapi menyeluruh dalam wilayah Kabupaten Ponorogo sehingga kebermanfaatannya pun akan lebih meluas.
\end{abstract}

Kata Kunci: Pengelolaan ZIS, Analisis pengelolaan ZIS, Meningkatkan perekonomian mustahik. 


\section{PENDAHULUAN}

Zakat, Infak, dan Sedekah (ZIS) adalah salah satu ibadah yang memiliki posisi yang sangat penting, strategis dan menentukan. Tentunya dapat dilihat dari sisi ubudiyah maupun dari pembangunan kesejahteraan ekonomi umat. Selain sebagai ibadah, ZIS juga memiliki keterkaitan sangat signifikan dengan dimensi sosial keummatan. Hal ini disebabkan secara substansif, pendayagunaan zakat secara material, dan fungsional. Kondisi tersebut memiliki partisipasi aktif dalam memecahkan permasalahan keummatan, seperti peningkatan kualitas hidup kaum dhuafa, peningkatan sumber daya manusia dan pemberdayaan ekonomi. Dalam hitungan makro, zakat dapat di maksimalkan sebagai institusi distribusi pendapatan di dalam konsepsi ekonomi Islam.

ZIS digadang sebagai salah satu instrumen dalam meningkatkan perekonomian masyarakat, terutama masyarakat dhuafa. Dimana dana ZIS yang terkumpul nantinya tidak hanya dibagikan secara konsumtif saja, akan tetapi diproduktifkan dalam bentuk-bentuk peningkatan ekonomi salah satunya guna menunjang permodalan UMKM atau usaha mikro yang dimiliki mustahik. Diharapkan dengan diberikannya bantuan permodalan akan mampu menjadi solusi bagi permasalahan yang membelit mereka selama ini. sehingga usaha yang dimiliki mampu bertahan dan jauh berkembang, dimana nantinya dari usaha mereka akan menggulirkan kesempatan pekerjaan bagi masyarakat lain dan tentunya melepaskan mereka dari bingkai kemiskinan. Sebagaimana yang kita ketahui bersama bahwa masalah kemiskinan ini menjadi momok yang seakan tiada habisnya dan tersebar hampir disetiap kabupaten.

Persoalan kemiskinan di kabupaten Ponorogo sendiri menjadi hal yang masih sulit dicarikan solusi. Sementara angka kemiskinan di Kabupaten Reyog ini pada tahun 2019 sekitar 9,64\%. Dalam lima tahun terakhir ada tren penurunan angka kemiskinan di Ponorogo. Pada tahun 2015 angka kemiskinan sebesar 11,91\%, 2016 sebesar 11,75\% 2017 sebesar 11,39\%, 2018 sebesar 10,36\%, dan 2019 sebesar $9.64 \%$. Salah satu penghambat kemiskinan adalah kultur (www.madiunpos.com). Oleh karena itu, hadirnya ZIS Produktif tentu membawa angin sejuk bagi pemberantasan masalah ini.

Pengelolaan distribusi zakat harus dilaksanakan tidak hanya secara konsumtif tetapi juga produktif, oleh karena itu peran LAZ ataupun BAZ menjadi sangat penting. Kedua lembaga tersebut harus mampu mengoptimalkan potensi yang ada disertai dengan pengelolaan yang baik dan bertanggungjawab guna rancangan ZIS sebagai peningkatan ekonomi mustahik melalui pemberian modal usaha mampu tercapai. Salah satu pelopor Lembaga Amil Zakat di Ponorogo yang konsisten memberikan modal ZIS produktif 

kepada mustahik adalah LAZISMU KL BMT Hasanah Ponorogo. Lembaga ini memiliki program pemberdayaan usaha mikro melalui sistem Al-Qardul Hasan yang disingkat BANKZISKA (Bantuan Keuangan Dari Dana Zakat Infaq Sedekah dan Dana Sosial Keagamaan Lainnya).

Berdasarkan latar belakang tersebut, maka peneliti tertarik untuk mengambil judul “Analisis Pengelolaan Zakat, Infak, Dan Sedekah (ZIS) Untuk Meningkatkan Perekonomian Mustahik (Studi Kasus LAZIZMU KL BMT Hasanah Ponorogo).” Tujuan dari penelitian tersebut adalah untuk menganalisis pengelolaan Zakat, Infak, dan Sedekah (ZIS) di LAZISMU KL BMT Hasanah Ponorog terkait dengan cara pengelolaan, fundraising, dan pendistribusian dana ZIS yang bermanfaat meningkatkan perekonomian mustahik. Adapun rumusan masalah dalam penelitian ini, yaitu sebagai berikut:

1. Bagaimana cara LAZIZMU KL BMT Hasanah Ponorogo untuk menghimpun dana ZIS dari masyarakat?

2. Bagaimana upaya amil zakat dalam mendistribusikan zakat untuk meningkatkan ekonomi mustahik?

3. Bagaimana strategi meningkatkan ekonomi mustahik yang dikelola oleh LAZIZMU?

\section{TINJAUAN LITERATUR}

\section{Zakat}

Zakat berarti at-thahuru (membersihkan atau mensucikan), demikian jugamenurut Abu Hasan Al-Wahidi dan Imam Nawawi. Zakat berarti al-Barakatu (berkah), artinya orang yang membayar zakat akan senantiasa dilingkupi keberkahan dari Allah SWT. Zakat juga bermakna an-Numuw yang artinya tumbuh dan berkembang. Makna ini menjelaskan orang yang menunaikan zakat hartanya akan senantiasa tumbuh dan berkembang. Zakat bermakna pula as-Shalahu (beres atau bagus), yakni orang yang menunaikan perintah zakat hartanya akan selalu bagus, tidak pernah bermasalah. (KEMENAG: 2013, 11-12)

Adapun secara istilah zakat bermakna mengeluarkan sebagian harta tertentu yang diwajibkan Allah SWT. Untuk diberikan kepada orang-orang yang berhak menerimanya dengan kadar tertentu, haul tertentu, dan memenuhi syarat serta rukun tertentu pula. Zakat sendiri merupakan ibadah yang memiliki nilai ganda, yakni sebagai Hablum minannas dan Hablum minallah atau bisa dikatakan sebagai hubungan horizontal antar sesama manusia dan vertikal antara manusia dengan penciptanya. (KEMENAG: 2013, 12) Beberapa ayat Al-Quran yang menjelaskan tentang zakat di antaranya QS. Al-Bayyinah: 5, yang artinya: 
Pengelolaan ZIS dalam Upaya Meningkatkan Perekonomian Mustahik| Fitriana. Dkk "Padahal mereka tidak disuruh kecuali supaya menyembah Allah

dengan memurnikan ketaatan kepada-Nya dalam (menjalankan)

agama yang lurus, dan supaya mereka mendirikan shalat dan

menunaikan zakat; dan yang demikian Itulah agama yang lurus",

Pengelolaan (manajemen) dalam zakat meliputi kegiatan pengumpulan (penghimpunan) penyaluran, pendayagunaan, pengawasan, dan pertanggungjawaban harta zakat. Kegiatan tersebut dilakukan oleh amil zakat sebagai pengelolanya. Dalam pengorganisasian zakat diperlukan beberapa prinsip, yaitu (Hadziq, 2013):

1. Pengelolaan harus berlandaskan Al-Qur'an dan As-Sunnah.

2. Keterbukaan

Pihak pengelola harus menerapkan manajemen yang terbuka dengan tujuan menumbuhkan kepercayaan masyarakat terhadap amil zakat.

3. Menggunakan manajemen dan administrasi modern.

4. Harus mengelola zakat dengan sebaik-baiknya.

Kewenangan dalam rangka mengelola zakat bervariasi di berbagai dunia, baik yang dikelola oleh negara, organisasi masyarakat, ataupun bahkan kedua-duanya memiliki peran di dalamnya. Di Indonesia sendiri, Zakat, Infak, dan Sedekah (ZIS) dikelola oleh lembaga independen yang telah diatur dengan Undang-Undang Nomor 23 Tahun 2011 Pengelolaan Zakat. Pengelolaan zakat di Indonesia dikelola oleh organisasi keagamaan masyarakat dan takmir-takmir masjid dengan sebuah lembaga yang dikenal dengan Lembaga Amil Zakat (LAZ). Seiring berjalannya waktu, maka muncullah Badan Amil Zakat (BAZ) yang dikelola oleh lembaga semi-pemerintah pada 1970an di Jakarta. Pada awalnya pemerintah mengeluarkan Undang-Undang Nomor 38 Tahun 1999 yang mengatur tentang pengelolaan zakat yang kemudian diamademen melalui UU Nomor 23 Tahun 2011. Dalam undang-undang tersebut, disebutkan bahwa pengelola zakat (amil) terdiri atas BAZNAS (Badan Amil Zakat Nasional) dan Lembaga Amil Zakat (LAZ), baik tingkat nasional, provinsi, dan kabupaten/kota.

\section{Infak}

Infak berasal dari kata "anfaqa" yang artinya keluar, yang berarti mengeluarkan sesuatu harta untuk kepentingan sesuatu yang tujuannya untuk mendapatkan ridho Allah. Infak yaitu mengeluarkan sebagian harta benda yang dimiliki untuk kepentingan yang mengandung kemaslahatan. Sedangkan menurut terminologi syariat, infak berarti mengeluarkan sebagian harta atau pendapatan/penghasilan untuk sesuatu yang diperintahkan ajaran Islam. Jika zakat ada nishabnya, infak tidak mengenal nishab. Infak 

juga sebagian kecil dari harta yang digunakan untuk kebutuhan orang banyak sebagai kewajiban yang dikeluarkan karena atas dasar keputusan diri sendiri. Pengertian dari infak juga merupakan sesuatu yang dibelanjakan untuk kebaikan. Infak juga tidak memilki batas waktu untuk begitu juga dengan besar dan kecilnya. Akan tetapi infak biasanya identic dengan harta yaitu sesuatu yang diberikan untuk kebaikan. Jika ia berinfak maka kebaikan akan kembali kepada dirinya sendiri, jika tidak melakukan infak maka tidak jatuh kepada dosa (Khairina, 2019).

Sementara menurut Hadziq (2013), infak merupakan amal sosial suka rela yang dilakukan oleh seseorang dan diberikan kebebasan kepada pemiliknya untuk menentukan jenis harta, kadar harta yang ingin ia keluarkan. Hal ini berbeda dengan zakat yang jenis dan kadarnya ditentukan oleh syara'. Jadi, sifat infaq itu lebih umum dari pada zakat. Beberapa manfaat dalam menyalurkan infaq diantaranya sebagai sarana pembersihan diri, bentuk realisasi kepedulian sosial, bentuk ungkapan rasa syukur kepada Allah, dan sebagainya. Adapun macam-macam Infak terbagi menjadi empat macam, yaitu:

1. Mubah yaitu mengeluarkan harta untuk hal-hal yang mubah seperti dalam usaha atau perdagangan.

2. Wajib yakni mengeluarkan harta untuk hal-hal yang wajib seperti dalam pembayaran maskawain, menafkahi istri dan keluarga, dan nazar.

3. Haram adalah mengeluarkan harta untuk untuk perkara haram seperti infaknya orang kafir untuk menghalangi syiar Islam.

\section{Sedekah}

Menurut Hadziq (2013), sedekah berasal dari kata shadaqah, yang berarti jujur atau benar. Orang yang suka bersedekah adalah orang yang benar pengakuan imannya. Menurut terminologi syariat, pengertian sedekah sama dengan pengertian infak, termasuk juga hukum dan ketentuan-ketentuannya. Hanya saja, jika infak berkaitan dengan materi, sedekah memiliki arti lebih luas, menyangkut hal yang bersifat non materiil. Adapun anjuran tentang bersedekah seperti dalam QS. Al-Baqarah: 254 yang artinya:

"Hai orang-orang yang beriman, belanjakanlah (di jalan Allah) sebagian dari rezki yang telah Kami berikan kepadamu sebelum datang hari yang pada hari itu tidak ada lagi jual beli dan tidak ada lagi syafa'at. dan orang-orang kafir Itulah orang-orang yang zalim"

Dalam ayat ini Allah menyuruh kita untuk sering bersedekah sebelum terjadinya hari kiamat yang tidak ada jual beli. Sedekah bisa memberikan dan mendatangkan syafaat ketika di akhir kelak bagi orang sering bersedekah. Baik sedekah fisik maupun materi 

keduanya akan mendapat pahala yang sama. Perbedaan Infak dan sedekah terletak pada batasan yang diberikan. Dalam syariat, pengertian sedekah sebenarnya sama dengan pengertian infak, termasuk di dalamnya hukum dan ketentuannya. Infak hanya terbatas pada materi berupa harta. Sementara sedekah mencakup lebih luas bukan hanya materi saja, tetapi juga non-materi, seperti senyuman. Jadi, sedekah maknanya lebih luas dibandingkan dengan infak dan sedekah.

\section{Pengelolaan ZIS}

Menurut (Ani Mardiantari, 2019) pengelolaan dana zakat, infak, dan sedekah yang dilakukan oleh suatu Lembaga Amil Zakat ataupun Badan Amil Zakat Meliputi:

\section{Analisis Perencanaan}

Perencanaan adalah sejumlah kegiatan yang telah ditentukan sebelumnya guna dilaksanakan pada suatu waktu tertentu dan dalam periode tertentu. Perencanaan pada LAZ atau BAZ memiliki titik utama yang berbeda0beda, namun secara umum akan terkait dengan kesejahteraan ekonomi mustahik, bagaimana caranya untuk meningkatkan perekonomian mereka ke arah yang lebih baik.

\section{Analisis Pengorganisasian}

Pengorganisasian diartikan sebagai pengaturan kerja bersama sumber daya keuangan, fisik dan manusia dalam suatu organisasi. Pengorganisasian di LAZ atau BAZ dengan organisasi laba lainnya memiliki perbedaan yang tidak terlalu kentara, antara lain adanya struktur organisasi yang jelas, pembagian tugas yang sesuai dengan kemampuan dan keahlian yang dimiliki, serta adanya koordinasi dan wewenang.

\section{Analisis Pelaksanaan}

Pada tahap ini lebih menekankan pada penghimpunan dana ZIS juga pendistribusiannya. Pelaksanaan penghimpunan dilakukan dengan beragam program dan strategi guna menarik sebesar-besarnya potensi yang ada untuk kemaslahatan ummat. Adapun pendistribusian yang dilaksanakan disesuaikan dengan program yang hendak dijalankan, baik berupa konsumtif maupun produktif.

\section{Analisa Pengawasan}

Bentuk pengawasan dilakukan pada masing-masing unit program terkait kegiatan mereka untuk tetap menjaga amanah. Adanya pelaporan LAZ atau BAZ 
Pengelolaan ZIS dalam Upaya Meningkatkan Perekonomian Mustahik| Fitriana. Dkk dilakukan guna tercapainya transparansi kepada masyarakat umum dan sebagai bentuk pertanggungjawaban.

\section{METODE PENELITIAN}

1. Teknik Pengumpulan Data

Penelitian ini menggunakan jenis penelitian kualitatif. Artinya, penelitian kualitatif lebih bersifat deskriptif, menekankan pada proses daripada produk atau outcome, melakukan analisis data secara induktif, lebih menekankan makna, dan dilakukan pada kondisi ilmiah (yakni peneliti langsung ke sumber data dan peneliti ialah instrument kunci). Selain itu, bersifat subjektif dari sudut pandang partisipan secara deskriptif sehingga hasilnya tidak dapat digeneralisasikan. Dengan kata lain, metode riset ini lebih bersifat memberikan gambaran secara jelas suatu permasalahan sesuai dengan fakta di lapangan (Bogdan \& Biklen, 2006 (sitat dalam Sugiyono, 2020)). Adapun pendekatan kualitatif sebagaimana yang diungkapkan oleh Bodgan dan Taylor (sitat dalam Moleong, 2018) sebagai prosedur penelitian yang menghasilkan data deskriptif berupa kata-kata tertulis atau lisan dari orang-orang dan perilaku yang diamati. Peneliti sendiri menggunakan pendekatan kualitatif dalam penelitian ini, karena peneliti tertarik dengan fenomena di lapangan, yaitu untuk untuk menganalisis bagaimana pengelolaan Zakat, Infak, dan Sedekah (ZIS) di LAZISMU KL BMT Hasanah Ponorog terkait dengan cara pengelolaan, fundraising, dan pendistribusian dana ZIS yang bermanfaat meningkatkan perekonomian mustahik.

Kemudian untuk penelitian tersebut termasuk ke dalam penelitian lapangan (field research) atau dapat juga dianggap sebagai metode untuk mengumpulkan data kualitatif dimana peneliti berangkat ke lapangan untuk mengadakan pengamatan tentang sebuah fenomena dalam suatu keadaan ilmiah (Moleong, 2018). Pada hakikatnya jenis penelitian ini memaparkan dan menggambarkan keadaan serta fenomena yang lebih jelas mengenai situasi yang terjadi dan peneliti langsung terjun ke lokasi atau tempat penelitian (Sugiyono, 2020).

2. Teknik Analisa Data

Pada penelitian ini, peneliti terjun langsung pada objek penelitian yakni lembaga yang diteliti, yaitu LAZISMU KL BMT Hasanah Ponorogo untuk menganalisis pengelolaan, fundraising, dan pendistribusian dana ZIS (Zakat, Infak, dan Sedekah) yang dapat meningkatkan perekonomian mustahik. Adapun teknik yang digunakan penyusun dalam menganalisa data, yaitu dengan cara wawancara, observasi, dokumentasi, dan triangulasi. Dalam wawancara dan observasi disini dilakukan kepada 

lima orang mustahik dan tiga karyawan LAZISMU KL BMT Hasanah Ponorogo. Dokumentasi disini didapatkan melalui data pribadi milik LAZISMU KL BMT Hasanah sendiri yang dibuktikan dengan data penerimaan ZIS dan laporan keuangan (arus kas) dari Januari sampai dengan Desember 2020.

\section{Tahapan Penelitian}

a. Persiapan

1) Menyusun rancangan penelitian

Penelitian yang dilakukan berangkat dari permasalahan yang diperoleh penulis di lapangan. Terkait dengan potensi dana ZIS produktif untuk meningkatkan perekonomian mustahik melalui pemberian modal usaha kecil dan menengah.

2) Memilih lokasi penelitian

Penelitian ini dilaksanakan di LAZISMU KL BMT Hasanah Ponorogo, dengan responden yang berada di Pasar Mlarak dan pasar Siman yang menerima bantuan modal dana ZIS produktif antara tahun 2020-2021.

3) Mengurus perizinan

Perizinan dilakukan dengan meminta surat pengantar dari pihak kampus untuk diserahkan kepada LAZISMU Ponorogo.

4) Menjajagi dan melihat keadaan

Proses penjajagan lapangan dilakukan selama dua minggu dengan mendatangi pasar-pasar yang menjadi target pemberian modal ZIS produktif LAZISMU Ponorogo. Dari sekian pasar yang ada akhirnya dipilih pasar Mlarak dan pasar Siman sebagai tempat mencari data.

5) Memilih informan

Informan yang dipilih adalah hasil sampling dari jumlah keseluruhan penerima dana ZIS produktif yang tersebar di pasar Mlarak dan pasar Siman.

6) Menyiapkan instrumen penelitian

Dalam penelitian ini instrumen penelitian yang digunakan diperoleh dengan teknik observasi, wawancara, studi dokumentasi baik yang dilakukan peneliti atau dokumentasi dari pihak LAZISMU KL BMT Hasanah Ponorogo.

b. Pengolahan data

1) Analisis data

Teknik yang digunakan untuk menganalisa data, yaitu dengan cara wawancara, observasi, dokumentasi, dan triangulasi. Dalam wawancara dan observasi disini dilakukan kepada lima orang mustahik dan tiga karyawan LAZISMU KL BMT Hasanah Ponorogo. Dokumentasi disini didapatkan melalui data pribadi milik 

LAZISMU KL BMT Hasanah sendiri yang dibuktikan dengan data penerimaan ZIS dan laporan keuangan (arus kas) dari Januari sampai dengan Desember 2020 .

2) Mengambil kesimpulan dan verifikasi

Setelah dilakukan penelitian dan pengumpulan data serta penganalisisan selanjutnya adalah menarik kesimpulan dari data-data yang diperoleh serta melakukan verifikasi terkait kevalidan data yang diperoleh.

3) Narasi hasil analisis

Pada tahap terakhir adalah melaporkan hasil penelitian dalam bentuk tulisan dan menggunakan pendekatan kualitatif metode deskriptif-analitis.

\section{HASIL DAN PEMBAHASAN}

\section{Potensi Zakat, Infak, dan Sedekah (ZIS) di Ponorogo}

Potensi ZIS dalam meningkatkan perekonomian masyarakat yang bertujuan untuk memajukan sesuatu kea rah yang lebih baik dari sebelumnya. Peran lembaga ZIS ini sangat dibutuhkan oleh banyak kalangan masyarakat. Peran ZIS memiliki peranan aktif dalam sektor perekonomian. Hal ini dikarenakan ZIS merupakan pungutan yang mendorong kehidupan ekonomi hingga tercapainmya kebutuhan tersebut. Dalam perekonomian Zakat, Infak, dan Sedekah memiliki fungsi yang tujuannya untuk meningkatkan kesejahteraan.

Mengacu kepada cara menghitung potensi zakat nasional oleh BAZNAS, yang bercermin pada negara muslim di Timur Tengah maupun Afrika, potensi zakat suatu negara adalah 2,5 persen dari Produk Domestik Bruto (PDB) nya. Misalnya saat ini PDB nya 4000 triliun, maka minimal potensi zakatnya 2,5\% x 4000 triliun $=100$ triliun. Berangkat dari data jumlah penduduk muslim di kabupaten Ponorogo, dan mengikuti cara perhitungan itu maka potensi zakat di kabupaten Ponorogo dapat dikalkulasi sebagai berikut. PDB regional, atau PDRB ADHK (Produk Domestik Regional Bruto Atas Dasar Harga Berlaku) Kabupaten Ponorogo tahun 2012 adalah sebesar 9,4 triliun. Maka potensi minimal zakatnya 2,5\% x 9,4 triliun $=0,235$ triliun $=235$ miliar. Jika yang bisa diserap $1 \%$ nya saja maka akan ditemukan 2,35 miliar. Itu hanya perhitungan zakat mal saja, tidak termasuk pendapatan dari sadaqah, kurban, zakat fitrah dan lainnya.

Untuk kalkulasi potensi zakat fitrah, bisa dihitung secara kasar seperti berikut: Jumlah penduduk kabupaten Ponorogo tahun 2012 berdasarkan data dari kantor Kementerian Agama kabupaten Ponorogo sebesar 1.013.789 jiwa. Yang beragama 

Islam 99,33 \% (1.007.074 jiwa). Perbandingan penduduk kategori miskin dengan penduduk dengan kategori kaya $=(11,7: 87,3)$. Mengikuti proporsi perbandingan itu, maka jumlah muslimnya dengan kategori kaya $(87,3 \%)=895.175$ jiwa, dan kategori miskin $(11,7 \%)=117.827$ jiwa. Zakat fitrah diasumsikan sebagai zakat perkapita. Apabila penduduk kategori kaya masing-masing membayar zakat fitrahnya 1 sha' beras atau dikonversi dengan uang sebesar Rp 20.000,- saja, maka zakat fitrah itu sebesar 895.175 X Rp 20.000,- = Rp 17.903.500.000,-.( Tujuh belas milyar sembilan ratus tiga juta lima ratus ribu rupiah). Jika dari penduduk muslim Ponorogo itu 50\% saja yang membayar fitrah, maka potensi zakat fitrahnya, 50\% X Rp 17.903.500.000,- = Rp 8.951.750.000,- (Delapan milliar sembilan ratus lima puluh satu juta tujuh ratus lima puluh ribu) rupiah. Begitu besarnya potensi yang ada apabila mampu terserap dan terkelola secara maksimal maka akan sangat mampu untuk mengentaskan kaum dhuafa dari jeratan kemiskinan. (Digilib.uinsby.ac.id)

\section{Program Pemberdayaan ZIS di LAZISMU Ponorogo}

Program tersebut menjadikan langkah sebuah organisasi menjadi terencana dan terealisasi dengan apik. Hal tersebut juga berlaku dalam organisasi nirlaba (tidak berorientasi pada laba/ keuntungan), program yang terdapat dalam sebuah lembaga nirlaba di orientasikan guna pendistrubusian dana Zakat, Infak, dan Sedekah (ZIS) hibah, serta dana sosial lainnya kepada mustahik. Program-program yang ada tidak hanya berupa konsumtif belaka (akan habis sekali waktu) seperti pemberian sembako atau uang tunai pun berupa program pemberdayaan atau produktif. Pada LAZIZMU Ponorogo sendiri untuk program yang bersifat konsumtif, seperti bazar sembako murah, pemberian santunan berupa uang tunai, program sembako gratis, dan program-program konsumtif lainnya yang dilakukan secara rutin. Diluar program konsumtif dan pemberdayaan seperti pemberian masker kepada pedagang di pasar-pasar, program pembersihan masjid setiap jumat.

Adapun program yang bersifat produktif bagi mustahik (orang kurang mampu/miskin) adalah dengan memberikan mereka sebuah usaha agar mereka memiliki penghasilan dan bisa mandiri secara finansial. Salah satunya dalam bidang peternakan, adalah dengan memberi mustahik sepasang ekor ayam jantan dan betina untuk mustahik kembangbiakkan. Diharapkan dengan pemberian ayam akan menjadi suatu kesibukan bagi mereka, dan terlebih apabila mampu berkembangbiak dengan baik bisa paling tidak membantu kebutuhan mereka.(Hasil wawancara: Tony Sasono, 36) 
kepada para pedagang kecil di pasar yang memiliki omset dibawah seratus ribu atau mereka yang tergolong orang miskin. Mustahik akan diberikan modal usaha dengan tujuan agar mereka bisa mengembangkan usahanya. Umumnya yang menjadi sasaran adalah pedagang jamu yang mangkal di pasar, pedagang capar dan semisalnya yang beromset dibawah seratus ribu. Program ini dilaksanakan dipasar daerah Sambit, Sawo, Jabung, Jetis, Tamansari, Bungkal, Coper, Grogol, dan Bondrang. Berdasarkan setiap program pemberdayaan yang telah dilakukan, amil akan tetap memantau dan memberikan bimbingan berupa ilmu kepada mustahik. Misal, apakah ayamnya berkembangbiak dengan baik atau justru tidak. Controling yang dilakukan bertujuan untuk memantau sekaligus membimbing para mustahik agar progresnya baik. (Hasil wawancara: Dwi Rahayu, 36)

\section{Penghimpun (Fundraising) Dana Zakat, Infak, dan Sedekah (ZIS) Di LAZISMU KL BMT Hasanah Ponorogo}

Penghimpunan dana atau yang lebih dikenal dengan istilah fundraising adalah kegiatan yang paling krusial dalam suatu lembaga nirlaba. Seorang fundraiser yang baik harus mampu mengkomunikasikan programnya dengan jelas dan menarik di depan calon donatur agar orang tersebut tertarik untuk berpartisipasi. LAZIZMU KL BMT Hasanah Ponorogo merupakan lembaga amil zakat sebagai sarana penyaluran Zakat, Infak, dan Sedekah (ZIS) dengan berbagai program yang bertujuan untuk pendistribusian kepada mustahik untuk memenuhi kebutuhan hidup dan meningkatkan taraf ekonominya, seperti:
a. Agama
b. Peternakan
c. Perdagangan
d. Sosial
e. Pemberdayaan ekonomi

Adapun sistem pengumpulan dana ZIS di LAZIZMU KL BMT Hasanah Ponorogo diantaranya:

a. Via fundraiser (sistem door to door)

Maksudnya ialah, setiap bulan fundraiser LAZIZMU akan datang ke tempat donatur yang dikehendaki sesuai dengan keberadaan donatur saat itu. Biasanya sebelum datang, fundraiser terlebih dahulu menghubungi donatur mengenai keberadaanya. Pada setiap donasi donatur akan diberikan slip bukti sebagai tanda bahwa mereka 
Pengelolaan ZIS dalam Upaya Meningkatkan Perekonomian Mustahik| Fitriana. Dkk telah berdonasi sekaligus untuk transparansi jurnal pemasukan dana ZIS. Fundraising yang dilakukan guna membidik calon donatur baru agar tertarik untuk menjadi donatur tetap, yang pertama adalah menyampaikan maksudnya dengan bahasa yang santun. Kemudian ajak komunikasi terlebih dahulu terkait programprogram yang ada.

b. Selain melalui fundraiser donatur juga dapat melakukan transaksi melalui via transfer antar bank. Cara ini lebih efektif digunakan jika lokasi donatur yang jauh dari lembaga ZI. (Hasil wawancara: Bambang Setiawan. 25)

\section{Pendistribusian ZIS Guna Meningkatkan Ekonomi Mustahik}

Adapun upaya pendistribusian menurut hasil wawancara dengan Ustadz Bambang selaku bagian dari LAZISMU adalah sebagai berikut: (Hasil wawancara: Bambang Setiawan. 25)

a. Kriteria mustahik ditentukan adalah delapan asnaf dan lebih menekankan pada dhuafa, janda miskin dan sebatang kara, adapun pada program yang bersifat pemberdayaan mustahik ditentukan adalah pedagang yang beromset dibawah seratus ribu serta ibu-ibu rumah tangga yang ekonominya kurang.

b. Selanjutnya setelah dipetakan mustahik serta tempatnya, dilakukan pentasyarufan ZIS baik yang berupa barang konsumtif ataupun produktif (modal usaha).

c. Amil akan tetap memonitoring sejauh mana perkembangan dengan bantuan dana produktif yang telah diberikan, apakah ada peningkatan atau tidak. Jika sudah ada peningkatan terlebih sudah bisa menjadi seorang muzakki, maka dana tersebut akan digulirkan kepada mustahik lain yang membutuhkan.

Selain dari hasil wawancara, adapun hasil observasi yang dapat dijelaskan melalui Tabel 1 yakni tentang data penerimaan ZIS di LAZIZMU KL BMT Hasanah Ponorogo tahun 2020:

Tabel 1

Penerimaan Dana ZIS di LAZISMU KL BMT Hasanah Ponorogo Tahun 2020

\begin{tabular}{|c|c|c|c|c|c|c|c|}
\hline \multirow{2}{*}{ NO } & \multirow{2}{*}{ BULAN } & \multicolumn{4}{|c|}{ PENERIMAAN } & \multirow{2}{*}{\multicolumn{2}{|c|}{ TOTAL ( BLN ) }} \\
\hline & & \multicolumn{2}{|r|}{ ZAKAT } & \multicolumn{2}{|c|}{ INFAQ } & & \\
\hline 1 & JANUARI & $\mathrm{Rp}$ & 5.418 .000 & & 6.778 .021 & & 12.196 .021 \\
\hline 2 & FEBRUARI & & 3.759 .400 & & 4.005 .000 & $R p$ & 7.764 .400 \\
\hline 3 & MARET & $\mathrm{Rp}$ & 1.200 .000 & $\mathrm{Rp}$ & 541.000 & $\mathrm{Rp}$ & 1.741 .000 \\
\hline 4 & APRIL & & 2.500 .000 & $R p$ & 4.243 .200 & $R p$ & 6.743 .200 \\
\hline 5 & MEI & & 1.500 .000 & $\mathrm{Rp}$ & 35.075 .917 & $\mathrm{Rp}$ & 36.575 .917 \\
\hline 6 & JUNI & Rp & 1.000 .000 & $R p$ & 839.200 & Rp & 1.839 .200 \\
\hline 7 & JULI & & 3.000 .000 & & 8.068 .237 & $R p$ & 11.068 .237 \\
\hline 8 & AGUSTUS & $\mathrm{Rp}$ & 3.500 .000 & $\mathrm{Rp}$ & 3.438 .360 & $\mathrm{Rp}$ & 6.938 .360 \\
\hline 9 & SEPTEMBER & $R p$ & - & $\mathrm{Rp}$ & 2.241 .000 & $\mathrm{Rp}$ & 2.241 .000 \\
\hline 10 & OKTOBER & $R p$ & 3.000 .000 & $\mathrm{Rp}$ & 3.831 .681 & $R p$ & 6.831 .681 \\
\hline 11 & NOVEMBER & $\mathrm{Rp}$ & 1.375 .000 & & 5.698 .600 & $\mathrm{Rp}$ & 7.073 .600 \\
\hline 12 & DESEMBER & $\mathrm{Rp}$ & - & $\mathrm{Rp}$ & 912.000 & $\mathrm{Rp}$ & 912.000 \\
\hline \multicolumn{2}{|c|}{ TOTAL ( TH ) } & \multicolumn{2}{|c|}{ Rp 26.252.400 } & \multicolumn{2}{|c|}{ Rp 75.672.216 } & \multicolumn{2}{|c|}{ Rp 101.924.616 } \\
\hline
\end{tabular}


Berdasarkan Tabel 1 tersebut, secara analitis matematis didapatkan hasil bahwa seberapa besar dana ZIS yang masuk ke dalam LAZISMU akan berbanding lurus dengan penerimaan manfaat yang akan dirasakan oleh mustahik. Artinya, ketika adanya penerimaan dari sektor zakat dan infaknya pada tiap bulannya, maka akan semakin besar pula pentasyarufannya, sehingga memberikan kemanfaatan yang lebih besar dan meluas pula. Sedangkan pada September dan Desember tidak ada penerimaan dari sektor zakat, tetapi dari sektor infak dan sedekahnya selalu tetap ada penerimaannya. Selain dapat dibuktikkan dari penerimaan dana ZIS yang dimiliki oleh LAZISMU KL BMT Hasanah melalui Tabel 1, maka dapat pula dijelaskan pada Tabel 2 yang menunjukkan laporan arus kas periode Januari sampai dengan Desember 2020.

Tabel 2

Laporan Arus Kas Periode Januari-Desember 2020 
Pengelolaan ZIS dalam Upaya Meningkatkan Perekonomian Mustahik| Fitriana. Dkk

\begin{tabular}{|c|c|c|c|c|c|}
\hline $\begin{array}{l}\text { BAITUL MAAL HASANAK } \\
\text { Laporan Arus Kas } \\
\text { Periode Januari } 2020 \mathrm{~s} /\end{array}$ & s/d Desember 2 & 2020 & & & \\
\hline SALDO TAHUN 2019 & & & & & \\
\hline Zakat & & & & & \\
\hline Infaq \& Sa & 7.494 & & & & \\
\hline Saldo Kas ta & tahun 2019 (A) & & & 7.494 & \\
\hline PENERIMAAN DANA M & AASYARAKAT & & & & \\
\hline Bulan & Zakat & Infaq & & & \\
\hline Januari & 5.418 .000 & 6.778 .021 & & & \\
\hline Februari & 3.759 .400 & 4.005 .000 & & & \\
\hline Maret & 1.200 .000 & 541.000 & & & \\
\hline April & 2.500 .000 & 4.243 .200 & & & \\
\hline Mei & 1.500 .000 & 35.075 .917 & & & \\
\hline Juni & 1.000 .000 & 839.200 & & & \\
\hline Juli & 3.000 .000 & 8.068 .237 & & & \\
\hline Agustus & 3.500 .000 & 3.438 .360 & & & \\
\hline Septembe & & 2.241 .000 & & & \\
\hline Oktober & 3.000 .000 & 3.831 .681 & & & \\
\hline Nopembeı & 1.375 .000 & 5.698 .600 & & & \\
\hline Desember & & 912.000 & & & \\
\hline Total & 26.252 .400 & 75.672 .216 & & & \\
\hline Total penerimaan Zakat & at dan Infaq ( B & & 101.924 .616 & & \\
\hline PENERIMAAN ANGSUR & RAN & & & & \\
\hline Bulan & Nominal & & & & \\
\hline Januari & (2) & & & & \\
\hline Februari & - & & & & \\
\hline Maret & - & & & & \\
\hline April & - & & & & \\
\hline Mei & - & & & & \\
\hline Juni & - & & & & \\
\hline Juli & - & & & & \\
\hline Agustus & - & & & & \\
\hline Septembe & - & & & & \\
\hline Oktober & - & & & & \\
\hline Nopembeı & - & & & & \\
\hline Desember & - & & & & \\
\hline Total penerimaan Angs & suran Qardh ( C & & - & & \\
\hline Total Kas Masuk ( $\mathrm{D}=\mathrm{B}+$ & + C) & & & 101.924 .616 & \\
\hline Saldo Kas Sebelum Pen & nyaluran Dana ( & $(E=A+D)$ & & & 101.932 .110 \\
\hline PENYALURAN DANA & & & & & \\
\hline Jenis & Bantuan Kem & Pembiayaan & Qardh & & \\
\hline Program P & 3.506 .800 & 200.000 & & & \\
\hline Program K & 4.008 .500 & - & & & \\
\hline Program S & 79.197.817 & - & & & \\
\hline Program E & & & & & \\
\hline Total & 86.713 .117 & 200.000 & & & \\
\hline Total Penyaluran Dana & (F) & & 86.913 .117 & & \\
\hline PENGGUNAAN DANA & & & & & \\
\hline Operasional Kantor ( G & & & 3.104 .700 & & \\
\hline Total Kas Keluar ( $\mathrm{H}=\mathrm{F}+$ & & & & & 90.017 .817 \\
\hline Saldo Kas Tahun 2020 & $(\mathrm{E}-\mathrm{H})$ & & & & 11.914 .293 \\
\hline
\end{tabular}

Sumber: Data Pribadi Milik LAZISMU KL BMT Hasanah Ponorogo (2020)

Berdasarkan Tabel 2 tersebut, maka didapatkan hasil bahwa seberapa banyak dana ZIS yang tersalurkan. Artinya, semakin baik pengelolaannya, karena dana yang berhasil terkumpul mampu terkelola dengan maksimal.

\section{KESIMPULAN}

Berdasarkan penelitian dan pembahasan tersebut, maka penelitian ini dapat disimpulkan yaitu:

1. Pengelolaan zakat, infaq, dan sodaqoh oleh LAZIZMU KL BMT Hasanah Ponorogo mentasyarufkan zakat untuk diberikan kepada masyarakat luas yang 
Pengelolaan ZIS dalam Upaya Meningkatkan Perekonomian Mustahik| Fitriana. Dkk menjadi sasarannya dengan cara membuat program secara terperinci dalam meningkatkan ekonomi masyarakat agar terangkat dari garis kemiskinan. LAZIZMU dan BMT Hasanah bekerja sama memiliki peran dalam meningkatkan pendapatan ekonomi masyarakat. Yaitu, dengan menjalankan program-program yang ada dan dengan memberikan tambahan modal berupa pemberian ayam dan lain-lain.

2. Penghimpunan zakat (fundraising) diawali dengan kegiatan perencanaan, meliputi perencanaan program serta pengumpulan data muzakki dan mustahik. Sebagai upaya pengumpulan zakat, lembaga lazizmu menyediakan berbagai fasilitas bagi muzakki. Berbagai kemudahan yang disediakan antara lain, layanan jemput zakat, layanan pembayaran lewat via bank. Dengan fasilitas tersebut diharapkan pengumpulan dana zakat akan meningkat. Lembaga LAZISMU setiap bulannya sudah mempunyai donatur tetap yang nanti pembayarannya akan di ambil oleeh amil dari lembaga tersebut setiap bulannya.

3. Pentasyarufan zakat kepada orang yang berhak menerima (mustahik) baik secara konsumtif atau produktif. Zakat wajib didistribusikan kepada mustahiq sesuai dengan syariat islam. Contoh program penyaluran LAZIZMU dengan membuat program sembako murah dan menyalurkan sembako yang dilakukan pada bulan ramadhan. 


\section{REFERENSI}

Pengelolaan ZIS dalam Upaya Meningkatkan Perekonomian Mustahik| Fitriana. Dkk

\section{Jurnal}

Digilib.uinsby.ac.id

Khairina, N. (2019). Analisis pengelolaan zakat, infak, dan sedekah (zis) untuk meningkatkan ekonomi dhuafa (studi kasus di lembaga amil zakat nurul hayat cabang medan. At-Tawassuth, (4), 160-184.

Mardiantari, Ani. (2019). Peranan Zakat, Infak dan Sedekah (ZIS) Dalam Upaya Meningkatkan Perekonomian Masyarakat Kota Metro (Studi Pada Lazisnu Kota Metro). DIKTUM: Jurnal Syariah dan Hukum, 17 (1), 151-165.

\section{Books}

Hadziq, M. F. (2013). Fiqih zakat, infaq, dan sedekah. Modul pembelakaran ekonomi ziswaf.

Kementerian Agama Republik Indonesia. (2013). Panduan Zakat Praktis. Modul Milik Kementerian Agama Republik Indonesia Direktorat Masyarakat Islam Direktorat Pendayagunaan Zakat

Moleong, L. J. (2018). Metodologi penelitian kualitatif. Bandung: PT. Remaja Rosdakarya Offset.

Sugiyono. (2020). Metode penelitian kualitatif. (Edisi ke-3). Bandung: Alfabeta.

\section{Newspaper}

Jalil, M. (2019, Oktober 22). Kemiskinan kultural masih jadi penghambat pengentasan orang miskin di ponorogo. Diunduh dari https://www.madiunpos.com/kemiskinankultural-masih -jadi-penghambat-pengentasan-orang-miskin-di-ponorogo1042051/amp.

www.madiunpos.com

\section{Hasil Wawancara}

Rahayu, Dwi. Hasil Wawancara: 36.

Sasono, Tony. Hasil Wawancara: 36.

Setiawan, Bambang. Hasil Wawancara: 25. 